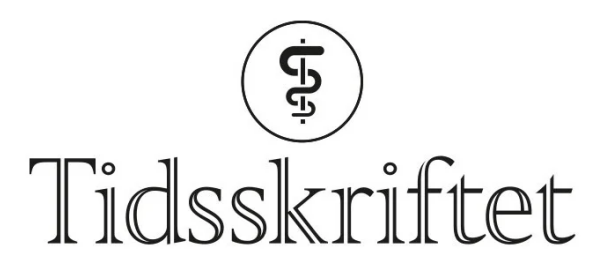

DEN NORSKE LEGEFORENING

\title{
Et fleksibelt arbeidsliv som lege - en utopi?
}

LEGELIVET

\section{INGRID HOKSTAD}

ihokstad@gmail.com

Ingrid Hokstad er lege i spesialisering i medisinsk biokjemi ved Sykehuset Innlandet.

\section{Koronapandemien har medført store endringer i} arbeidslivet. Kan leger også få større valgfrihet rundt når og hvor de utfører jobben sin? Og hva risikerer arbeidsgivere som ikke tilpasser seg ansattes forventninger om økt fleksibilitet i arbeidshverdagen?

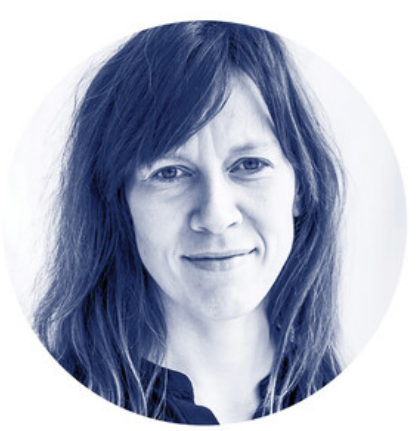

Koronaviruset infiserte både luftveier og arbeidslivet på sin ferd: Hjemmekontor er den nye normalen, erklærte media. Fleksible arbeidstider ble det nye mantraet. Folk lærte seg å benytte digitale møteløsninger, arbeidsgivere oppdaget at de ansatte faktisk kunne få gjort oppgavene sine hjemmefra også.

I helsevesenet fungerte smittevernhensyn som en katalysator for $\varnothing \mathrm{kt} \mathrm{bruk} \mathrm{av}$ videokonsultasjoner, og man fikk endelig tilpassede (riktignok midlertidige) takster for dette arbeidet. Noen kurs i spesialistutdanningen ble digitaliserte, og leger som ikke jobbet klinisk, ble henvist til hjemmekontoret. Men når pandemien er et tilbakelagt kapittel, hvordan vil endringene i arbeidslivet påvirke oss videre? De fleste leger jobber tross alt med pasienter, hvilket selvfølgelig setter visse krav til forutsigbar bemanning og fysisk tilstedeværelse. Likevel tror jeg forventningene om større fleksibilitet i arbeidshverdagen vil sive inn i legestanden også. Hvis partner og bekjente oftere kan jobbe hvor og når de vil, er det grunn til å tro at leger også vil søke seg over i stillinger med lignende vilkår. 
Faktisk ser vi allerede at dyktig fagpersonell velger å jobbe for bemanningsbyråer i stedet for å være fast ansatt i det offentlige helsevesenet. Slik kan de tjene bedre, jobbe mindre og ha større innflytelse over egen arbeidsdag. Idet kommersielle aktører står klare med fristende arbeidskontrakter, kan konsekvensen bli at det offentlige tappes for nøkkelpersonell. Det er et paradoks at vi tar oss råd til å bruke svimlende summer på innleid personell, men ikke til å tilby bedre betingelser for eksisterende ansatte.

Jeg kjenner mange flinke kolleger som har meldt overgang til private helsetilbydere eller til stillinger utenfor helsevesenet. Selv om jeg har stor forståelse for at enkeltpersoner gjør slike valg, blir jeg jo lei meg på det offentlige helsevesenets vegne: Menneskene som jobber i helsevesenet utgjør den desidert viktigste ressursen der, og pasienten blir taperen dersom vi ikke klarer å rekruttere og beholde gode fagfolk.

«Det er et paradoks at vi tar oss råd til å bruke svimlende summer på innleid personell, men ikke til å tilby bedre betingelser for eksisterende ansatte»

I primærhelsetjenesten er fastlegeordningen på randen av sammenbrudd flere steder, og arbeidsgiver har ikke lenger råd til å være kravstor. Der tilbys goder som ekstra ferie, fri bolig, barnehageplass og «nordsjøturnus» for å tiltrekke seg søkere. I tillegg til en god lønn, selvfølgelig. Trolig vil mange fristes av jobber med mulighet for større fleksibilitet hva arbeidstid og sted angår. Det etableres stadig nye helsetjenestetilbud der det er en reell mulighet. Samtidig er det fordeler i den tradisjonelle legetilværelsen som man ikke får noe annet sted, og som gjør at man kanskje er villig til å fire på andre krav. Vi er privilegerte som kan gå til faglig spennende og meningsfylte jobber, hvor forskning, undervisning og tilhørighet til et fagmiljø er viktige faktorer.

Selv om vi vet at en positiv organisasjonskultur er forbundet med bedre pasientbehandling (1), fokuseres det forsvinnende lite på kunnskapsledelse i helsevesenet - altså på hvordan man kan benytte den ansattes ressurser best mulig og skape strukturer og praksiser som legger til rette for maksimal utnyttelse av den kompetansen som finnes i virksomheten. Da mener jeg ikke i form av fokus på kvantitet, hvor mange DRG-poeng man kan «produsere» eller hvor raskt man klarer å skrive ut pasienter, men hvordan vi blir bedre på kvalitet. Fokus på generiske ferdigheter som hvordan man lærer, motiveres, løser problemer, kommuniserer, samarbeider, utnytter tiden eller skaper gode team, er nærmest fraværende. Vi tar oss rett og slett ikke tid til å finne ut hvordan vi bruker tiden vår på den best mulige måten. Kanskje er det fordi leger allerede innehar mange slike ferdigheter - det må til for å komme inn på studiet - og man praktiserer det i hverdagen, men det ville være naivt å anta at vi ikke har et forbedringspotensial likevel.

\section{«Menneskene som jobber $i$ helsevesenet utgjør den desidert viktigste ressursen der, og pasienten blir taperen dersom vi ikke klarer å rekruttere og beholde gode fagfolk»}

Selvsagt kan vi ikke i våre jobber forvente utstrakt bruk av hjemmekontor eller frie arbeidstider - det sier seg selv. Likevel finnes det kanskje rom for innovasjon i hvordan vi organiserer oss? Må papirarbeidet tas på jobb mellom kl. 8 og 16? Kan morgenfuglen komme kl. 6 og gå kl.14? Kan B-mennesket holde kveldspoliklinikk eller gå mellomvakter fra kl. 12-20? Er dagens struktur med morgenmøte, visitt og papirarbeid etter lunsj «fasiten» på optimal organisering? Må man i det hele tatt ha faste arbeidstider?

Kanskje er det naivt å tenke at vi skal få til de store omveltningene i organiseringen av arbeidsdagen, men spørsmålet er om vi har råd til å la være? Jeg tror ikke flinke folk har lyst til å forlate jobbene sine, men de vil selvfølgelig ha gode lønns- og arbeidsvilkår. Uavhengig 
av realismen i det: Hadde vi klart å tilby større fleksibilitet i arbeidshverdagen, tror jeg vi hadde fått enda mer dedikerte arbeidstakere - og prima pasientbehandling på kjøpet.

\section{LITTERATUR}

1. Braithwaite J, Herkes J, Ludlow K et al. Association between organisational and workplace cultures, and patient outcomes: systematic review. BMJ Open 2017; 7: e017708. [PubMed][CrossRef]

Publisert: 28. april 2021. Tidsskr Nor Legeforen. DOI: 10.4045/tidsskr.21.0294

(C) Tidsskrift for Den norske legeforening 2023. Lastet ned fra tidsskriftet.no 26. april 2023. 